\title{
Staling of sponge cakes with added emulsifiers
}

\author{
MARIA MARUDOVA $^{1 *}$ (D), STANKO STANKOV ${ }^{2}$ and MARIANNA BAEVA ${ }^{2}$ \\ ${ }^{1}$ University of Plovdiv "Paisii Hilendarski", 24 Tzar Assen str., 4000 Plovdiv, Bulgaria \\ ${ }^{2}$ University of Food Technology, 26 Maritza Blvd, 4002 Plovdiv, Bulgaria
}

\section{CONFERENCE FULL PAPER}

Received: August 11, 2020 • Accepted: September 22, 2020

Published online: November 18, 2020

(C) 2020 The Author(s)

\begin{abstract}
The effect of three types of emulsifiers (polyglycerol monostearate ester - E475, sucrose stearate ester E473 and modified inulin palmitate ester - HP-25) on the starch retrogradation in sponge cake (SC) during storage was investigated. The method of differential scanning calorimetry (DSC) was applied to determine the changes in the starch retrogradation during the staling process. The retrogradation temperature and the enthalpy of the endothermic transition decreased when emulsifiers were added. The lowest values of the enthalpy for the whole storage period were found for SC with 1\% HP-25. The methods of differential thermal analysis (DTA) and thermogravimetry analysis (TGA) showed significantly bigger (1.43 times) amount of strongly bound water in the crumb of the SC with E475 and HP-25 in comparison to the control sample on the sixth day of storage. Based on our results, emulsifiers possessed retarding effect on the starch retrogradation and extend the shelf-life of the SC.
\end{abstract}

\section{KEYWORDS}

sponge cake, emulsifiers, storage, starch retrogradation, DSC

\section{INTRODUCTION}

Food industries are increasingly solicited by the consumers regarding the preservation of foodstuffs during storage. The control of the latter necessarily depends on the understanding of

\footnotetext{
*Corresponding author. E-mail: marudova@uni-plovdiv.net
} 
molecule interactions within food as well as physical and chemical reactions during storage. Preservation of baked products (e.g., breads, cakes, biscuits, etc.) is of particular interest because storage conditions influence their organoleptic and nutritional qualities (Botosoa et al., 2015; Díaz-Ramírez et al., 2016). The aging of these matrices, all composed of flour (gelatinized starch and gluten) with limited quantities of water, is called staling. Previous studies on the staling process of bread have emphasized the importance of drying (as a result of water migration) and starch recrystallization or "retrogradation" (Botosoa et al., 2015; Wang et al., 2015).

Sponge cakes are high ratio, low fat, foamed type of cakes that rely on incorporated air for volume and texture (Díaz-Ramírez et al., 2016). The egg white is whipped to form foam and then other ingredients like flour, sugar, yolk, are gently folded in. The egg protein matrix with its air incorporation forms the structure of the cake as it bakes. The high-quality sponge cakes have various attributes, including a good volume with a uniform crumb structure, tenderness and the ability to retain the crumb softness during storage (Gomez et al., 2007) that could be achieved by applying different types of emulsifiers (Wang et al., 2015). It has been reported that emulsifiers increase air incorporation, decrease specific gravity, produce a finer fat dispersion and as a result increase the final cake volume (Eduardo et al., 2016; Rahmati and Tehrani, 2014). The most important factor affecting the function of an emulsifier is its physical state. The emulsifiers used for cake baking should be in the $\alpha$-gel state to create a stabilizing film to cover the bubble surfaces (Jyotsna et al., 2004). An emulsifier functions in two ways. It aids in the incorporation of air and disperses the shortening in smaller particles to give the main number of available air cells (Sahi and Alava, 2003). Emulsifiers possess antistaling characteristics, explained by their ability to form insoluble complexes with amylose, their limited reaction with amylopectin, and their strengthening effects on doughs by interaction with flour proteins, and also maximize the inclusion of moisture (Seyhun et al., 2003). In this regard, some of the most suitable emulsifiers in $\alpha$-gel state, which are used to enhance aeration properties of the sponge cakes, are Glycerol monostearate (GMS), Sorbitan fatty-acid esters (O'Brien, 2004) and Inulin palmitate ester (Petkova et al., 2012).

The objective of this work was to study the influence of various types of emulsifiers on the retrogradation of wheat starch in sponge cakes during storage.

\section{MATERIALS AND METHODS}

\section{Preparation of sponge cakes}

Standard raw materials such as wheat flour - ash $0.5 \%$, sugar and eggs were bought from the local market. Three different emulsifiers are considered as optional additives and are used as cake improvers: polyglycerol monostearate ester (E475) (Radiamuls Poly 2248K) (Oleon Group, Belgium), sucrose stearate ester (E473) (Sisterna SP70-C) (SISTERNA, Netherlands) and modified inulin palmitate ester (HP-25), produced by University of Food Technologies, Department of Organic Chemistry and Microbiology, Bulgaria. The emulsifiers were added to the formulation at $1 \%$ (amount based on the batter). A control sample of cake batter was included in the study. Ingredients based on flour weight are: egg yolk - 43.22\%, egg white $96.77 \%$, sugar -83.87 , wheat flour $-100.00 \%$. The mixture for the control sample was prepared following a traditional technology and formulation (Angelov et al., 1974), according to a doublebowl mixing procedure. The recipe for making batter included preliminary separation of egg 
whites and yolks. The batter with the addition of emulsifier as an emulsifier gel, is prepared by a single-bowl mixing process of the components.

The sponge cakes were baked in a metallic pan containing $120 \mathrm{~cm}^{3}$ of batter and placed in an electric oven for $30 \mathrm{~min}$ at $180{ }^{\circ} \mathrm{C}$. The sponge cakes were prepared in laboratory conditions.

The sponge cakes, stored at standard conditions (temperature of $18{ }^{\circ} \mathrm{C}$ and $75 \%$ relative humidity), were investigated up to the sixth day after the production date according to standard requirements (Bulgarian State Standard 4636-82, clause 6.4.2.3). Longer storage period up to 21 days was necessary for the sponge cakes investigated by differential scanning calorimetry (DSC), because no retrogradation transition was registered up to the sixth day. The humidity and the temperature were kept constant in desiccator, situated in a thermostat, with accuracy of \pm 0.5 deg.

\section{Physico-chemical characteristics of the sponge cakes}

The starch retrogradation was studied by DSC 204F1 Phoenix (Netzsch Geräebau GmbH, Germany). The calorimeter was calibrated by indium standard. The sponge cake crumb samples $(15 \mathrm{mg}$ ) were closed hermetically in aluminum pans and heated in the calorimeter from 20 to $150{ }^{\circ} \mathrm{C}$ at a rate $10{ }^{\circ} \mathrm{C} / \mathrm{min}$ (Ji et al., 2007). Each measurement of cake crumb was twice repeated.

The content of strongly and slightly bound water as a percentage of total bound water in the cake crumb was determined by differential thermal analysis (DTA) and thermogravimetry analysis (TGA) (Madhava et al., 2001). DTA included differential thermogravimetry (DTG) and DTA curves, while TGA included TGA and T (temperature) curves. These methods were based on the measurement of sample mass change as a result of moisture release on heating. The content of strongly and slightly bound water was determined by the quantity change of energy used for water evaporation under continuous heating (Panchev et al., 2005). Both DTA and TGA investigations were carried out by SETSYS Evolution 2500 instrument (SETARAM, France) and performed at $5{ }^{\circ} \mathrm{C} / \mathrm{min}$ heating rate covering the temperature range $20-150{ }^{\circ} \mathrm{C}$. The sample mass was $15 \pm 0.5 \mathrm{mg}$. Each measurement of cake crumb was repeated three times.

The water activity $\left(a_{w}\right)$ of the crumb samples at different aging times was measured using Novasina $12 \mathrm{CH}-8853$ (Switzerland) at $20{ }^{\circ} \mathrm{C}$. Crumbled samples were put in the sample cups and hermetically covered before analysis to avoid moisture loss or gain. Data are reported as the mean of three measurements on 1st, 3rd and 6th day during the storage of the cakes.

The received data was analyzed by one-way-ANOVA test and the significant differences were determined by Fisher's least significant difference (LSD) procedure $(P=0.05)$.

\section{RESULTS AND DISCUSSION}

Four sponge cakes formulations were investigated in the present study: control sample (no added emulsifier), sample with 1\% E475, sample with 1\% E473, and sample with 1\% HP-25.

An important indicator of the sponge cakes staling is the water state in the system. Summarized data from the TGA curves for the amount of the total bound water $(W)$, slightly bound water $\left(W_{1}\right)$ and strongly bound water $\left(W_{2}\right)$ are presented in Table 1 . The amount of the total bound water $(W)$ depends on the type of the components in the batter formulation and the water activity $\left(a_{w}\right)$ of the crumb of the baked cake (Table 2) (Antal et al., 2014). The sponge cakes containing emulsifiers, are characterized by significantly higher content of the $\mathrm{W}$ in the 
Table 1. Bound water ${ }^{1}$ changes in the crumb of sponge cakes during storage

\begin{tabular}{|c|c|c|c|c|c|c|}
\hline \multirow[t]{2}{*}{$\begin{array}{l}\text { Storage } \\
\text { (days) }\end{array}$} & $W_{1}(\%)$ & $W_{2}(\%)$ & $W(\%)$ & $W_{1}(\%)$ & $W_{2}(\%)$ & $W(\%)$ \\
\hline & \multicolumn{3}{|c|}{ Control sample } & \multicolumn{3}{|c|}{ Sponge cake with $1 \%$ HP-25 } \\
\hline 1 & $2.01 \pm 0.37^{\mathrm{a}}$ & $25.73 \pm 2.17^{\mathrm{a}}$ & $27.74 \pm 1.80^{\mathrm{a}}$ & $1.83 \pm 0.40^{\mathrm{a}}$ & $32.97 \pm 3.87^{\mathrm{b}}$ & $34.80 \pm 3.47^{\mathrm{b}}$ \\
\hline 3 & $1.84 \pm 0.12^{\mathrm{a}}$ & $25.31 \pm 0.24^{\mathrm{a}}$ & $27.15 \pm 0.12^{\mathrm{a}}$ & $1.87 \pm 0.28^{\mathrm{a}}$ & $31.39 \pm 1.91^{\mathrm{b}}$ & $33.26 \pm 2.20^{\mathrm{b}}$ \\
\hline \multirow[t]{2}{*}{6} & $1.93 \pm 0.05^{\mathrm{b}}$ & $19.59 \pm 1.37^{\mathrm{a}}$ & $21.52 \pm 1.32^{\mathrm{a}}$ & $1.70 \pm 0.26^{\mathrm{a}}$ & $27.62 \pm 1.19^{c}$ & $29.32 \pm 0.93^{c}$ \\
\hline & \multicolumn{3}{|c|}{ Sponge cake with $1 \%$ E475 } & \multicolumn{3}{|c|}{ Sponge cake with $1 \%$ E473 } \\
\hline 1 & $1.85 \pm 0.06^{\mathrm{a}}$ & $32.32 \pm 0.58^{\mathrm{b}}$ & $34.17 \pm 0.64^{\mathrm{b}}$ & $2.02 \pm 0.10^{\mathrm{a}}$ & $37.10 \pm 0.03^{c}$ & $39.12 \pm 0.07^{\mathrm{C}}$ \\
\hline 3 & $2.63 \pm 0.22^{b}$ & $33.20 \pm 0.29^{c}$ & $35.83 \pm 0.5^{\mathrm{b}, \mathrm{c}}$ & $2.20 \pm 0.60^{\mathrm{a}}$ & $31.14 \pm 2.09^{\mathrm{b}}$ & $33.34 \pm 2.69^{b}$ \\
\hline 6 & $2.48 \pm 0.69^{c}$ & $28.24 \pm 0.54^{\mathrm{c}}$ & $30.72 \pm 1.23^{c}$ & $1.63 \pm 0.15^{\mathrm{a}}$ & $24.49 \pm 0.20^{\mathrm{b}}$ & $26.12 \pm 0.35^{\mathrm{b}}$ \\
\hline
\end{tabular}

a,b,c: Significant differences are determined at a certain day for all the samples.

${ }^{1}$ Two states of total bound water $(W)$ determined by thermogravimetry analysis: $W_{1}$ - slightly bound water; $W_{2}$ - strongly bound water.

Table 2. Water activity $\left(a_{w}\right)$ of the sponge cakes crumb during storage

\begin{tabular}{lcccr}
\hline Storage, [days] & Control & with $1 \% \mathrm{HP}-25$ & with $1 \% \mathrm{E} 475$ & with $1 \% \mathrm{E} 473$ \\
\hline 1 & $0.808 \pm 0.001^{\mathrm{a}}$ & $0.899 \pm 0.001^{\mathrm{b}}$ & $0.908 \pm 0.003^{\mathrm{c}}$ & $0.898 \pm 0.001^{\mathrm{b}}$ \\
3 & $0.818 \pm 0.002^{\mathrm{a}}$ & $0.898 \pm 0.003^{\mathrm{b}}$ & $0.903 \pm 0.002^{\mathrm{b}}$ & $0.894 \pm 0.003^{\mathrm{b}}$ \\
6 & $0.903 \pm 0.001^{\mathrm{c}}$ & $0.820 \pm 0.002^{\mathrm{b}}$ & $0.816 \pm 0.004^{\mathrm{a}}$ & $0.833 \pm 0.001^{\mathrm{b}}$ \\
\hline
\end{tabular}

${ }^{\mathrm{a}, \mathrm{b}, \mathrm{c}}$ : Significant differences are determined at a certain day for all the samples.

crumb compared to the control sample. On the first day of storage, the lowest value for the $\mathrm{W}$ was recorded in the control sample $(27.74 \%)$ and the lowest value for the water activity $\left(a_{w}\right)$ was also measured in the control sample $\left(a_{w} \approx 0.808\right)$ (Table 2$)$. The highest value for the $W$ of the crumb on the first day of storage is reported for the sponge cake with $1 \%$ E473 (39.12\%), which has a higher $a_{w}$ compared to the control sponge cake. The amount of the $\mathrm{W}$ in all four types of sponge cakes decreases during the storage. Table 1 shows that the $W$ and the $W_{2}$ of the sample with 1\% HP-25 and with 1\% E475 decrease more moderately during the storage of these sponge cakes, especially until the 3rd day, where close values for the $\mathrm{W}$ and for its two states are established, and the maintenance of a uniform ratio between them in favor of the $W_{2}$ is observed. This fact determines the equal temperatures $\left(50^{\circ} \mathrm{C}\right)$, at which the two states of the $\mathrm{W}$ are separate in these cakes up to the 3rd day of the storage. A gradual decrease in the amount of the bound water is observed between the 3rd and 6th day of storage, without significantly changing the relative ratio of the $W_{2}$.

The decrease in the $W$ is the lowest in the sponge cake with $1 \% \mathrm{E} 475$ and on the 6 th day of storage the loss is $3.45 \%$. The $W$ on day 6 th day for the sponge cake with $1 \% \mathrm{E} 473$ declined by $13.00 \%$ and for the sponge cake with $1 \%$ HP- 25 by $5.48 \%$ respectively. On the 6 th day of storage, the highest value for the $a_{w}$ was recorded for the control sponge cake, and the lowest value for the crumb of sponge cake with $1 \% \mathrm{E} 475$. The lower values for the $a_{w}$ in the sponge cakes with the three types of emulsifiers on the 6th day of storage show smaller water chemical potential, i.e., during the storage the higher percent of the water is $W_{2}$ to the other cakes' ingredients 
Table 3. Values of the thermal transitions

\begin{tabular}{llccccc}
\hline & $\Delta T\left({ }^{\circ} \mathrm{C}\right)$ & $T_{p}\left({ }^{\circ} \mathrm{C}\right)$ & $\Delta H(\mathrm{~J} / \mathrm{g})$ & $\Delta T\left({ }^{\circ} \mathrm{C}\right)$ & $T_{p}\left({ }^{\circ} \mathrm{C}\right)$ & $\Delta H(\mathrm{~J} / \mathrm{g})$ \\
\cline { 2 - 7 } Storage, (days) & \multicolumn{3}{c}{ Control sample } & \multicolumn{2}{c}{ Sponge cake with $1 \% \mathrm{HP}-25$} \\
\hline 7 & $67.3 \div 85.4$ & 83.3 & 0.375 & $61.2 \div 80.2$ & 70.3 & 0.083 \\
14 & $57.4 \div 81.5$ & 69.6 & 0.477 & $62.3 \div 82.0$ & 68.8 & 0.216 \\
21 & $62.1 \div 84.0$ & 75.6 & 0.919 & $44.1 \div 68.4$ & 52.7 & 0.370 \\
\cline { 2 - 7 } & $56.6 \div 65.1$ & 62.1 & 0.055 & $41.8 \div 47.2$ & 45.3 & 0.139 \\
& \multicolumn{2}{c}{ Sponge cake with $1 \% \mathrm{E} 475$} & \multicolumn{2}{c}{ Sponge cake with $1 \% \mathrm{E} 473$} \\
\hline 7 & $51.9 \div 57.7$ & 55.3 & 0.431 & $40.6 \div 47.4$ & 47.4 & 0.214 \\
21 & $51.1 \div 58.0$ & 55.6 & 0.623 & $43.0 \div 47.8$ & 45.5 & 0.397 \\
\hline
\end{tabular}

(Tables 1 and 2). On the 6th day of storage, the sponge cake with 1\% E475 is characterized with the highest percentage of $W_{2}$, which is $8.65 \%$ more than the control sponge cake. On the 6th day of storage, $W_{2}$ in the sponge cakes with $1 \%$ HP-25 and with $1 \%$ E473 was $8.03 \%$ and $4.90 \%$ more than that of the control sponge cake. As far as the lowest changes in the values of the $\mathrm{W}$ and its two states were determined for the crumb of sponge cakes with 1\% E475 and 1\% HP-25 (Table 1), it could be concluded that the water-retention effect is the highest in the sponge cakes with 1\% E475 and 1\% HP-25 and correlates to the slowest stalling.

The starch retrogradation during the sponge cakes storage is characterized by an endothermic melting process of the starch crystal regions (Table 3 and Fig. 1).

It is clear from the obtained DSC curves, that the temperature interval $(\Delta T)$ and the enthalpy $(\Delta H)$ of the endothermic phase transition determine the degree of sponge cakes stalling during the storage. No endothermic phase transition was recorded during the first 6 days of the storage for all the four types of sponge cakes; therefore, data were not available for this storage period. The temperature of the endothermic peak $\left(T_{p}\right)$ on the 7 th day of storage for the control sponge cake is the highest $\left(83.3{ }^{\circ} \mathrm{C}\right)$, and its endothermic phase transition includes the widest temperature range in the comparison with the sponge cakes with added emulsifiers. The lowest endothermic peak temperature on the 7 th day of storage was recorded for the sponge cake with $1 \%$ E473 $\left(45.3^{\circ} \mathrm{C}\right)$.

Considering the fact, that the least change in the amount of the bound water and especially in the $W_{2}$ is recorded in the sponge cake with $1 \% \mathrm{E} 475$, it is logical that the water retaining effect in this sponge cake is the most pronounced and that the lowest degree of staling is observed for it. Most probably this is the reason that the lowest value for starch retrograde enthalpy (0.055 J/ g) on the 7th day of storage, was recorded for the sponge cake with $1 \% \mathrm{E} 475$, followed by the sponge cake with $1 \% \mathrm{HP}-25(0.083 \mathrm{~J} / \mathrm{g})$. Therefore, maintaining high values for the $\mathrm{W}$ and the low values of the $a_{w}$ in the sponge cakes with E475 and HP-25 emulsifiers affects the freshness of the cakes during the storage, slowing down the starch retrogradation.

It is considered by a number of researchers (Botosoa et al., 2015; Díaz-Ramírez et al., 2016; Wang et al., 2015) that the energy input during the heating can be directed in two ways: breaking down the complex between the emulsifiers and the starch, and breaking down the bonds between the water and the starch. Depending on the rate of starch amylose deposition during the storage, the endothermic phase transition of the crystalline structure of the 

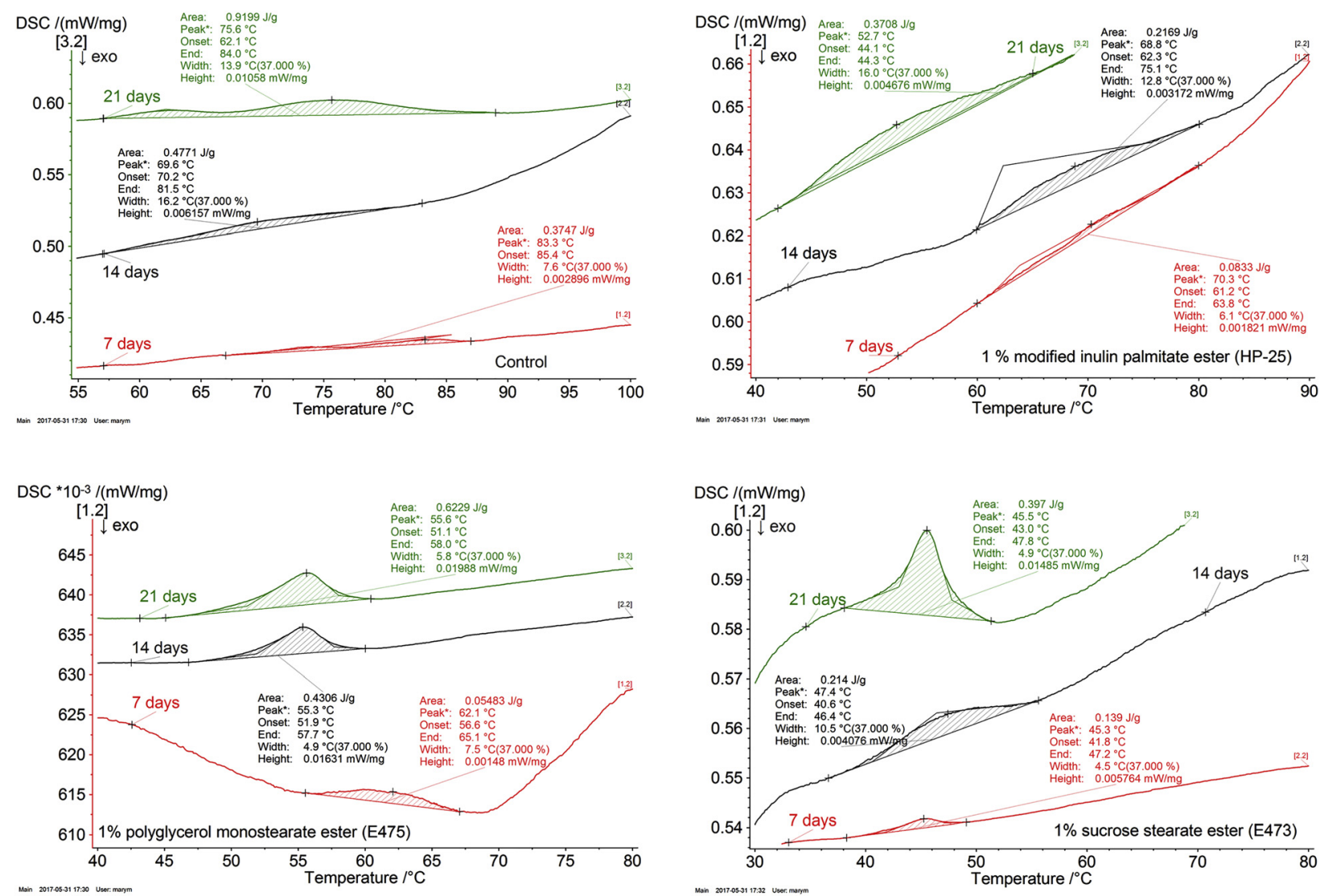

Fig. 1. Starch retrogradation during the sponge cakes storage, studies by DSC 
retrogradated amylose fraction is formed. Higher energy levels of these thermal transitions may explain the presence of amylose crystal accumulation zones in a sponge cake without emulsifiers whose melting requires a higher temperature (Table 3 ).

The emulsifiers influence the deposition processes of the starch crystals by their complexing ability with the amylose chain, whereby a lower melting temperature of the crystal lattice is observed (Table 3). Low enthalpy values show less deposited crystalline parts of starch during the storage. The heat input, used for the destruction of the starch crystalline regions in the control sponge cake is the highest in the whole time of investigation - from the 7 th $(0.375 \mathrm{~J} / \mathrm{g})$ to the $21 \mathrm{st}$ day of storage $(0.919 \mathrm{~J} / \mathrm{g})$ in comparison to the other sponge cakes with added emulsifiers, which significantly lower their energy levels. The lowest values of the enthalpy on the 21st day of detection in the newly obtained sponge cakes with added emulsifiers, were found for sponge cake with $1 \% \mathrm{HP}-25(0.370 \mathrm{~J} / \mathrm{g})$, which corresponds to the strongest anti-stalling properties of the used emulsifier. The highest energy level of a sponge cake with emulsifier on the 21 st day of storage is reported for sponge cake with $1 \% \mathrm{E} 475(0.623 \mathrm{~J} / \mathrm{g})$.

The use of HP-25 and E475 emulsifiers significantly slows the crystalline deposition process due to the preservation of the complex between the emulsifier and the starch, and in this way the freshness of the sponge cakes during the storage is preserved.

\section{CONCLUSIONS}

1. Only insignificant changes in the amount of the total bound water and the amount of the strongly bound water in the sponge cakes with 1\% E475 and 1\% HP-25 during storage of 6 days were observed.

2. The lowest value of the retrogradation enthalpy on the 21 st day of the storage was read for the sponge cakes with 1\% HP-25 and with 1\% E473. This fact proves the retarding effect of the both emulsifiers on the starch retrogradation.

3. Keeping high levels of both the total and the strongly bound water, as well as reaching of low water activity levels for the sponge cakes with E475 and HP-25 emulsifiers during the storage, affect the freshness of the cakes in way of slowing the starch retrogradation.

\section{REFERENCES}

Angelov, L., Bekirov, B., Genadieva, M., and Atanasov, S. (1974). OH 146 200-72. In: Handbook of branch standards, rates of consumption and technological instructions in confectionary, Vol. 1. CKS, Sofia, pp. 176-183.

Antal, T., Sikolya, L., and Kerekes B. (2014). Quality evaluation of different pre-treatments and combined convective-freeze drying of sour cherry (Prunus Cerasus L.). Progress in Agricultural Engineering Sciences, 10: 17-33.

Botosoa, E.P., Chèné, C., Blecker, C., and Karoui, R. (2015). Nuclear magnetic resonance, thermogravimetric and differential scanning calorimetry for monitoring changes of sponge cakes during storage at $20{ }^{\circ} \mathrm{C}$ and 65\% relative humidity. Food and Bioprocess Technology, 8: 1020-1031. 
Díaz-Ramírez, M., Calderón-Domínguez, G., Chanona-Pérez, J.J., Salgado-Cruz, M.D.L.P., AndracaAdame, J.A., and Ribotta, P.D. (2016). Sponge cake microstructure, starch retrogradation and quality changes during frozen storage. International Journal of Food Science and Technology, 51: 1744-1753.

Eduardo, M., Svanberg, U., and Ahrné, L. (2016). Effect of hydrocolloids and emulsifiers on the shelf-life of composite cassava-maize-wheat bread after storage. Food Science \& Nutrition, 4: 636-644.

Gomez, M., Ronda, F., Caballero, P.A., Blanco, C.A., and Rosell, C.M. (2007). Functionality of different hydrocolloids on the quality and shelflife of yellow layer cakes. Food Hydrocolloids, 1: 167-173.

Ji, Y., Zhu, K., Qian, H., and Zhou, H. (2007). Staling of cake prepared from rice flour and sticky rice flour. Food Chemistry, 104(1), 53-58.

Jyotsna, R., Prabhasankar, P., Indrani, D., and Venkateswara Rao, G. (2004). Improvement of rheological and baking properties of cake batters with emulsifier gels. Journal of Food Science and Technology, 69: 16-19.

Madhava, M., Srinivasa Rao, P., and Goswami, T. K. (2001). Drying kinectics of paddy using thermogravimetric analysis. Drying Technology, 19: 1201-1210.

O’Brien, R.D. (2004). Fats and oils: formulating and processing for applications. CRC, Boca Raton.

Panchev, I.N., Baeva, M.R., and Lambov, S.I. (2005). Influence of edible films upon the moisture loss and microstructure of dietetic sucrose-free sponge cakes during storage. Drying Technology: An International Journal, 23: 925-940.

Petkova, N., Todorova, M., Nikovska, K., and Denev, P. (2012). New fatty acid esters of soluble dietary fibers with emulsifying properties. Narossa, Magdebourg, Germany, CD Frequency range, $\mathrm{cm}-1$ Experimental IR bands, cm-1 Assignment.

Rahmati, N.F. and Tehrani, M.M. (2014). Influence of different emulsifiers on characteristics of eggless cake containing soy milk: Modeling of physical and sensory properties by mixture experimental design. Journal of Food Science and Technology, 51: 1697-1710.

Sahi, S.S. and Alava, J.M. (2003). Functionality of emulsifiers in sponge cake production. Journal of the Science and of Food Agriculture, 83: 1419-1429.

Seyhun, N., Sumn, G., and Sahin. S. (2003). Effects of different emulsifier types, fat contents, and gum types on retardation of staling of microwave-baked cakes. Nahrung/Food, 47, 248-251.

Wang, S., Li, C., Copeland, L., Ni, Q., and Wang, S. (2015). Starch retrogradation: a comprehensive review comprehensive. Reviews in Food Science and Food Safety, 14, 568-585.

Open Access. This is an open-access article distributed under the terms of the Creative Commons Attribution-NonCommercial 4.0 International License (https://creativecommons.org/licenses/by-nc/4.0/), which permits unrestricted use, distribution, and reproduction in any medium for non-commercial purposes, provided the original author and source are credited, a link to the CC License is provided, and changes - if any - are indicated. 